\title{
THE "RIGHT TO COUNSEL" IN POLITICAL CASES: THE BAR'S FAILURE
}

\section{DAVID GOLDBERGER*}

Throughout American history, the few lawyers willing to appear in unpopular political cases have been forced to endure blistering personal and professional attacks for their efforts. These attacks continue today. In the face of such attacks, the vast majority of American lawyers avoid political cases. Most lawyers support the attacks-either by actually joining in the attacks or by looking the other way when others make them. Unless there is a change in the bar's attitude and conduct, unpopular political clients will face a severe shortage of competent legal representation because very few able lawyers will be willing to endure the attacks.

To illustrate my point, I would like to refer to my own experience in the Skokie case. ${ }^{1}$ In that case, a small group of self-styled Nazis sought to picket the village hall in Skokie, Illinois, a predominantly Jewish community. Skokie became the subject of intense public interest because it is the residence of a comparatively large number of concentration camp survivors and survivors of Nazi-occupied Europe. The Nazis stated that all they planned to do was to protest an insurance bond requirement blocking their use of Skokie's public parks. They planned to appear in storm trooper uniforms and display the swastika.

Four days prior to the scheduled assembly, the village of Skokie filed suit, seeking an injunction barring the uniforms, the swastika, and all potentially offensive language. The strategy behind the litigation appeared to be that if the paraphernalia were barred, the group itself would stay at home.

Late in the evening of the day the suit was filed, I received a phone call from the leader of the Nazi group, who requested representation by the American Civil Liberties Union (ACLU) in court the next morning. I conferred with appropriate officials of the ACLU Illinois Division about whether we should take the case. We rapidly concluded that the case posed classic first amendment questions, leaving us with no choice but to take it.

\footnotetext{
* Legal Director, ACLU, Illinois Divison.

1. National Socialist Party of America v. Village of Skokie, 432 U.S. 43 (1977); Village of Skokie v. National Socialist Party of America, 51 Ill. App. 3d 279, 366 N.E.2d 347 (1977), aff'd in part, rev'd in part, 69 Ill.2d 605, 373 N.E.2d 21 (1978); Goldstein v. Collin, No. 50176 (Ill. Jan. 27. 1978); Collin v. Smith, 578 F.2d 1197 (1978).
} 
I then made several efforts to find a volunteer attorney to take the case. Each person I asked refused because of the short notice or because of distaste for the client. At that point, the hour was growing late; and it was quite clear that no one but I, teamed with a part-time volunteer attorney, was willing or able to appear in the case. We did so the following morning. An injunction was issued that afternoon against any assembly in which the party members appeared with uniforms, swastikas, or literature.

The reaction of the community to the ACLU taking the case was predictably hostile. After all, what could be a more offensive client of fact situation in a first amendment case? The Chicago ACLU office was swamped with angry telephone calls, letters of resignation, and ultimately some threats of violence. It is my understanding that some people opposing our representation quietly approached ACLU funding sources to discourage donations and grants.

More disturbing, however, was the reaction of the bar. First I must emphasize-thankfully-that a small number of lawyers who had supported the ACLU for a long time understood the responsibility of the bar to appear in unpopular cases: they provided as solid a base of support as they could. Unfortunately, their support was dwarfed by the reaction of the vast majority of the members of the bar who expressed either indifference or outright hostility because the ACLU had provided counsel. All bar associations stood by silently.

Several attorneys resigned from the Illinois ACLU in anger as soon as they learned of our involvement. For example, a former state official resigned, stating that he did not believe the organization should defend individuals or groups whose philosophy is not consistent with democracy. He avoided the question of whether the conduct was lawfully protected by the first amendent.

When the case was discussed at a meeting of a group of lawyers in private practice, many of them, including a municipal court judge, vigorously expressed the sentiment that the case should never have been taken by the ACLU. They said that if the Nazis had gone unrepresented, an injunction would have been issued against its activities and no one would have paid any attention to the matter. Instead, these lawyers complained, the ACLU's provision of counsel had made the group too newsworthy.

Because of the tradition of the criminal defense bar of providing representation in unpopular criminal cases, it was assumed that its members in particular would understand and actively support the ACLU's decision to provide counsel. Therefore, the ACLU sent a letter to a number of criminal defense attorneys in Chicago, seeking their support in hopes of offsetting the criticism and membership losses that had been generated by the case. The letter quoted the ethical consideration of the Canons of Ethics, which requires lawyers to ap- 
pear in unpopular cases. ${ }^{2}$ The response was silence. A criminal court judge later observed privately that the criminal defense bar was not sympathetic to defense efforts in the Skokie case because most members of the criminal bar found the client's views intolerable.

Former Attorney General Edward Levi, a University of Chicago law professor, broke his agreement to put his name on a public statement urging people not to abandon the ACLU solely because of the Skokie case. Levi justified this refusal on grounds that he was not an ACLU member.

As the most visible lawyer in the case, I came in for a substantial share of the criticism and vituperation. In one court document, I was called "neo-Nazi counsel." 3 (When I objected, the lawyer who made the statement assured me that he meant only "counsel for the neo-Nazis." 4 He said it was like calling counsel for a labor union a "union lawyer.") Personally insulting telephone calls poured into my office. When I appeared at speaking engagements, I was repeatedly called a Nazi sympathizer or a dupe. At one speaking engagement at a synagogue in Gary, Indiana, a small radical political group attempted to disrupt the program long enough to present me with an award for being "Nazi of the Year."

As of the date of this speech, no organized bar group has made a statement or suggestion that the appearance of counsel in the case was constitutionally necessary or, for that matter, ethically proper. None has even considered the question.

A cursory reading of the Canons of Ethics and of American judicial history suggests that the right to counsel even in unpopular political cases is so settled a question that the organized bar should have become concerned as soon as the criticism began to mount. The Canons of Ethics are quite articulate on the subject. The Canons contain an ethical consideration that states, among other things, "Regardless of his personal feelings, a lawyer should not decline representation because a client or a cause is unpoplar or a community reaction is adverse." This statement, of course, is hedged by other statements making it clear that "a lawyer is under no [legal] obligation to act as advisor or advocate for every person." Nonetheless, the ethical consideration sets out an ideal against which the bar is presumed to measure its conduct.

The importance of counsel in political cases hardly needs to be discussed. The adversary system is premised on the notion that sound judicial decisions

2. aba Canons of Professional Ethics, Ethical Considerations, $2-27$ (1969).

3. Goldstein v. Collin, $77 \mathrm{CH} 4367$ (Cook County Circuit Court) (plaintiff's motion to quash deposition, July 7, 1977).

4. Supra note 3. Oral argument in opposition to defendant's motion to dismiss, Sept. 1, 1977 and telephone conversation with counsel.

5. Supra note 2.

6. Id. $\$ 2-26$. 
are products of cases vigorously contested on all sides. To permit a political dissident to go through the court system without a lawyer or with inept representation can generate only poor decisions. This should be a troubling prospect, particularly in cases that turn on vital constitutional questions. Thus, in the words of Justice Hugo Black, "Just as a democratic society needs legislators willing and able to criticize national and state policy, so it needs lawyers who will defend unpopular causes and champion unpopular clients." 7

The principle that underlies the portion of the Canons of Ethics encouraging lawyers to undertake the representation of unpopular clients is rooted deeply in English tradition. The English actually forbid their barristers from declining to provide representation in cases in which they have basic expertise. ${ }^{8}$

E. V. Rostow, former dean of the Yale Law School, tells us that the obligation of the English barrister to undertake any case tendered to him was acknowledged in Scotland as early as the sixteenth century. ${ }^{9}$ As to England, he quotes Sir Hartley Shawcross, former chairman of the General Council of the English Bar, who observed that:

It arose in 1792 over the prosecution of Tom Paine for publishing the second part of his Rights of Man. The great advocate Erskine, who accepted the retainer to defend Paine and was deprived of his Office as Attorney General to the Prince of Wales for doing so, said-and said truly-in a famous speech: "From the moment that any advocate can be permitted to say that he will or will not stand between the Crown and the subject arraigned in the court where he daily sits to practice, from that moment the liberties of England are at an end." 10

In the American colonies, it appeared superficially that there was to be deference paid to the English tradition. For example, there is the timeworn story of the courage of John Adams at the time of the Boston Massacre. Several colonists had been killed by British soldiers during a shooting incident that the colonists believed tantamount to cold-blooded murder. ${ }^{11}$ A Captain Prescott was thought to have ordered a group of British soldiers to fire, leading to the killings. Adams was asked to defend Prescott, who vigorously denied giving the order. ${ }^{12}$ In the face of intense public outrage, Adams agreed to undertake the defense and announced his intentions openly. ${ }^{13}$ His defense was successful.

7. Law Students Civil Rights Research Council, Inc. v. Wadmond, 401 U.S. 154, 180 (1971) (Black, J., dissenting).

8. H. Drinker, Legal Ethics 139 (1953).

9. Rostow, The Lawyer and His Client, 48 A.B.A.J. 25, 29 (1962).

10. The Times (London), Feb. 19, 1953, at 4, col. 3

11. See Report of the Committee of the Town of Boston to Thomas Pownall (March 12, 1770), reprinted in F. Kidder, History OF THE Boston MASSACre 2 l-23 (1870).

12. See H. Zobel, The Boston Massacre 216 (1970).

13. See generally 3 Diary Ani Autobrography of John Adams 293-95 (L. Butterfield ed. $1961)$. 
There are other prominent examples of adherence to the tradition that a lawyer has an ethical obligation to appear in unpopular cases. For example, there is the case in which the Maryland lawyer Roger Taney represented Pastor Gruber, a Methodist minister who had sermonized against slavery while attending a camp meeting in Washington County, Maryland. ${ }^{14}$ At the time, Maryland was a slave state, and abolitionist views were considered an anathema to public order. The minister was indicted on charges that his speech was an incitation of slaves to insurrection. Taney undertook the defense on behalf of Pastor Gruber in the face of enormous public hostility throughout the state; he won an acquittal. ${ }^{15}$

Unfortunately, these examples of lawyers' individual commitment to the principle of the bar's obligation to appear in unpopular cases are the exception rather than the rule. For the most part, the English tradition never took root in America, and members of the private bar have assiduously avoided involvement in political cases like the Skokie suit.

One of the most embarrassing examples of the bar's treatment of controversial political cases occurred during the McCarthy period. Defense of communists under the various anticommunist laws of the period was shunned by the bar and was left to a few lonely lawyers who, for lack of adequate alternatives, had to appear in case after case. ${ }^{16}$ As a result, they quickly became identified with their clients, reducing their effectiveness. In an article published in 1961, Leon Jaworski noted the disturbing nature of the bar's treatment of the communist cases: "Particularly disquieting is the growing tendency of members of the Bar to shun the acceptance of representation on the side that meets with public disfavor." 17

For a time it seemed that the problem of representation in unpopular cases might be addressed systematically when the U.S. Supreme Court ruled in Gideon $v$. Wainuright ${ }^{18}$ that indigent criminal defendants have a constitutional right to counsel. To no one's surprise, the Court's decision generated no moral rebirth among members of the private bar. Rather, it resulted in the creation of large court-supervised public defender organizations which were insulated from criticism and attack by public funding.

Gideon did not create a right to counsel for indigents in civil cases, so the Johnson administration's "War on Poverty" created the federally funded legal aid program that ultimately became the Legal Services Corporation. Like public defenders, legal aid lawyers found insulation from attack in controversial cases in public funding. Not that the insulation is complete. During the Nixon administration, for example, Congress made strenuous efforts to limit the abil-

14. See, e.g., W. Lewis, Without Ffar or Favor 76-77 (1965).

15. Id. at 77 .

16. See C. Belfrage. The American Inquisition, 1945-1960, at 177 (1973).

17. Jaworski, The Unpopular Case, 47 A.B.A.J. 714,714 (1962).

18. 372 U.S. 335 (1963). 
ity of legal services attorneys to sue the government. ${ }^{19}$ These were largely unsuccessful. However, legal services lawyers are presently barred from representing women desiring elective abortions in cases challenging the validity of anti-abortion laws. ${ }^{20}$

When the Skokie case arose, the Nazis who were named as defendants neither qualified for legal aid nor for the public defender. They therefore had to turn to the private bar, where the response was as I have already described.

Admittedly, the problems of American dissidents may appear insubstantial to many in comparison to problems of dissidents in countries governed by dictatorships. However, the undoubtedly true horror stories about the problems of dissidents abroad should not be permitted to obscure the seriousness of problems in the United States.

There are great costs imposed by the American bar's hostility or indifference towards the problems in representing dissidents. The most obvious and important one is as I have already stated: truly unpopular dissidents simply may be denied access to legal representation. This point hardly needs elaboration. Almost every member of the private bar confronted with the possibility of losing clients whose fees guarantee a livelihood or suffering public vilification for representing an unpopular client will refuse such representation.

Another cost of bar indifference in political cases is debilitation of basic civil liberties. The public looks to the bar as an example and as a source of information on civil liberties questions. To the extent that the bar ignores or attacks its own members in difficult civil liberties cases, the public is taught to do the same thing. How can we then expect the public to embrace basic civil rights, such as the right to counsel, when the bar apparently does not?

Finally, there is the cost of the bar's hostility and indifference to the judicial process. Failure of the organized bar to support the work of attorneys in unpopular cases not only exposes those attorneys to attack but also exposes the courts to attack. It is one short step from vilifying the ACLU and its lawyers for advocating and defending first amendment rights to vilifying the courts for upholding those rights. In fact, it was only a few years ago that the American Bar Association attacked the Supreme Court for civil liberties rulings, compelling Chief Justice Warren's resignation from the association.

What can and should the organized bar do in the face of such a long record of hostility or indifference? The answers are clear. The organized bar must:

1. Speak out publicly on behalf of lawyers who appear in extremely unpopular cases. The bar's silence and the attacks by its members are intolerable for the reasons I have already explained. The organized bar, therefore, must establish a policy of routinely issuing public resolutions and state-

19. See 119 Conc. Rec. 20685, 20736-20740 (1973).

20. 42 U.S.C. $\S 2996 f$. 
ments on behalf of the right to counsel in particular cases whenever necessary. It should not wait to be asked. A repudiated request for help is even more damaging than silence-the requests will therefore never materialize.

2. Financially support the civil liberties organizations when possible. After all, those are the organizations that frequently fill the void in the availability of counsel in political cases created by the ideological preferences or business necessities of members of the private bar.

3. Explain, even in private conversations with nonlawyers, the importance of the right to counsel in unpopular cases. There is no better way to communicate the importance of the right to counsel-especially in the more distasteful cases-than on a one-to-one basis. Bar members must take time to educate the public about the right to counsel and the related duties of lawyers.

4. Stop avoiding appearing in unpopular cases as a matter of course. This proposal is the most obvious and least palatable approach. The Canons of Ethics make the responsibility clear. Undertaking the responsibility is the most direct remedy to the present state of affairs. The bar might even consider adopting the English approach and limiting the discretion of lawyers to reject such cases.

In spite of these suggestions, continued failure of the bar to reconsider its traditional posture of inaction or hostility in political cases is probably to be expected. It seems as if the only thing capable of stirring the American bar is Chief Justice Warren Burger's assertion that many lawyers are incompetent in the courtroom. Nonetheless, because the strength of the Bill of Rights depends, in large part, on the commitment of the American bar to it, one can always hope that the bar one day will choose to measure up to the ideal that it claims to espouse. 